\title{
Growth and yield of Maize hybrids as effected by different sowing Dates in Swat Pakistan
}

Imran $^{1 *}$, Izaz Hussain ${ }^{1}$, Shahida Naveed ${ }^{2}$, Salim Shah ${ }^{3}$, Aziz Ur Rahman ${ }^{4}$, Hayat Zada ${ }^{5}$, Inayat Ullah ${ }^{1}$, Asad Ali Khan ${ }^{1}$ and Subhan Uddin ${ }^{6}$

1. Department of Agronomy, The University of Agriculture Peshawar, Pakistan

2. Department Botany, Government Girls Degree College, Karak, Pakistan

3. Department of Plant Breeding and Genetics, Bacha Khan University Charsadda, Pakistan

4. Department of Plant breeding and genetics, The University of Agriculture Peshawar, Pakistan

5. Department of Plant Protection, The University of Agriculture Peshawar, Pakistan

6. Department of Agricultural Mechanization, The University of Agriculture Peshawar, Pakistan

*Corresponding author's email: imranagrarian@aup.edu.pk

Citation

Imran, Izaz Hussain, Shahida Naveed, Salim Shah, Aziz Ur Rahman, Hayat Zada, Inayat Ullah, Asad Ali Khan and Subhan Uddin. Growth and yield of Maize hybrids as effected by different sowing Dates in Swat Pakistan. Pure and Applied Biology. Vol. 5, Issue 1, 2016, pp114-120. http://dx.doi.org/10.19045/bspab.2016.50015

\begin{tabular}{llll}
\hline \hline Received: 09/09/2015 & Revised: 12/01/2016 & Accepted: 20/01/2016 & Online First: 01/02/2016 \\
\hline \hline
\end{tabular}

\section{Abstract}

To evaluate the response of maize hybrids to different sowing Dates, an experiment was conducted during kharif season, at farmer field school, Sambat cham, Matta, Swat, during summer 2012. The experiment was carried out in randomized complete block design with split plot arrangement having four replications. Sowing date (June $1^{\text {st }}, 15^{\text {th }}, 30^{\text {th }}$ ) was allotted to main plots, while maize hybrids (PIONEER-30K08, CS 200 and MALKA-TS-1105) were sown in sub plots. A subplot size of $3.5 \mathrm{~m} \times 4.0 \mathrm{~m}$ was used. Each subplot was consisted of six rows having 75 $\mathrm{cm}$ row-to-row distance with row length of $3 \mathrm{~m}$. Sowing either on $1^{\text {st }}$ or $15^{\text {th }}$ June gave at par grains ear $^{-1}$ (560 and 563), grain yield (7820 and $9010 \mathrm{~kg} \mathrm{ha}^{-1}$ ) and biological yield (25055 \& $\left.23240 \mathrm{~kg} \mathrm{ha}^{-1}\right)$ respectively. Sowing on $15^{\text {th }}$ June gave higher plant height $(232 \mathrm{~cm})$. Delayed sowing on $30^{\text {th }}$ June decreased grains ear ${ }^{-1}$ to 460 , grain yield to $6060 \mathrm{~kg} \mathrm{ha}^{-1}$, biological yield to $15972 \mathrm{~kg} \mathrm{ha}^{-1}$ and plant height to $185 \mathrm{~cm}$. There was no effect of sowing dates on ear $\mathrm{m}^{-2}$ and thousand grains weight. Among the maize hybrids, PIONEER-30K08 had the optimum number of ears $\mathrm{m}^{-2}(7)$, grain yield (8343 $\left.\mathrm{kg} \mathrm{ha}^{-1}\right)$ and biological yield (22129 $\mathrm{kg} \mathrm{ha}^{-1}$ ) while Malka-TS1105 showed the lowest grain yield of $7119 \mathrm{~kg} \mathrm{ha}^{-1}$ and biological yield of $20231 \mathrm{~kg} \mathrm{ha}^{-1}$. The hybrids did not differ from each other in plant height. On the basis of the above results, among the tested hybrids PIONEER-30K08 is recommended for sowing on either June 1st or $15^{\text {th }}$ June undr the agro-ecological conditions of Swat valley.

Key words: Maize (Zea mays L.); Sowing Dates; Hybrids; Farmer field school (FFS)

\section{Introduction}

Maize (Zea mays L.) belongs to family poaceae. In Pakistan maize is third most important cereal crop after wheat and rice
[1]. It is an annual, determinate crop, having $\mathrm{C}_{4}$ carbon fixation pathway. It is a short duration crop and is grown twice a year both for grain and fodder purpose [2]. 
It is cultivated both in spring and kharif seasons in Pakistan, due to the availability of temperate as well as tropical genetic material both in hybrids and open pollinated maize varieties. Maize is a dominant crop in the farming system because it is a staple food crop for much of rural population. Its grain is used for several industrial purposes such as starch, alcohol, corn sugar, corn oil, acetones and lactic acid. Besides its multipurpose uses, corn is getting popularity for its non-cholesterol oil content in the present day world [3]. Corn grain is valuable source of protein $(10.4 \%)$, fat $(4.5 \%)$, starch $(71.8 \%)$, vitamins and minerals like calcium, phosphorous and sulfur. It also provides raw materials to starch industry and is used in the preparation of many products. It is grown throughout Khyber Pakhtunkhwa [4]. About two-third of the total world production of maize is used for livestock feed or for commercial starch and oil production [5]. In Pakistan, maize was cultivated on an area of 0.974 million ha with an annual production of 3.707 million tones and an average yield of $3805 \mathrm{~kg} \mathrm{ha}^{-1}$ in Pakistan, whereas in Khyber Pakhtunkhwa average yield of maize crop was $1751 \mathrm{~kg}$ $\mathrm{ha}^{-1}$ during the reported year [6]. Soil and climatic conditions of Pakistan are highly favorable for corn production. But unfortunately in Khyber Pakhtunkhwa and especially in Swat district yet its average yield is very low. The reasons for low yield are non-availability of high yielding hybrids, improper use of fertilizer, and insufficient availability of irrigation water at proper time, improper sowing date and lack of modern production technology. Among the various factors of crop production, improved hybrids and proper sowing dates play key role in boosting production of corn [7]. High yielding hybrids are of primary importance for higher yield. Hybrids play vital role in successful maize husbandry [8].
Yield can be increased to a greater extent provided high yielding hybrids are identified and planted at optimum sowing dates. A comparative study of maize hybrids is necessary in order to sort out the most reliable hybrids for agro-climatic conditions of Swat [9, 10]. The main objective of this experiment was to screen out high yielding hybrid(s) that can mature in short period of time with very little or no effects on yield. In this experiment three dates of sowing have been used i.e. $1^{\text {st }}$ June, $15^{\text {th }}$ June and $30^{\text {th }}$ June. Sowing of different hybrids on different sowing dates might give us a clue regarding the best hybrid(s) and suitable planting date(s) that might result in higher or at least somewhat normal yield under irrigated condition of Swat valley.

\section{Materials and Methods}

To study the effect of various sowing dates on yield and yield attributes of maize hybrids, an experiment was conducted at Farmer Field School, Sambat cham, Matta Swat, Pakistan during summer 2012. The experiment was laid out in randomized complete block (RCB) design with split plot arrangement having four replications. Previous crop in the field was spring wheat (Triticum aestivum L.). Sowing dates were allotted to main plots, while maize hybrids were allotted to sub plots. A subplot size of $3 \mathrm{~m} \times 4.5 \mathrm{~m}$ was used. Each sub plot was consisted of 6 rows having $75 \mathrm{~cm}$ row-torow distance with row length of $3 \mathrm{~m}$. All the recommended agronomic practices were followed. Three sowing dates June $\left(1^{\text {st }}, 15^{\text {th }}\right.$, $\left.30^{\text {th }}\right)$ and three hybrids i.e. PIONEER30K08, CS 200, and MALKA-TS-1105 were used. Data were recorded on plant height $(\mathrm{cm})$, ears $\mathrm{m}^{-2}$, grains ear $^{-1}, 1000$ grain weight, grain yield and biological yield. Plant height was measured at harvesting stage. Plant height form ground level to the last node of the five randomly selected plants in each subplot was 
measured through measuring tape and averaged. Ears in one meter square area at three different places in each subplot were counted and averaged to record ears $\mathrm{m}^{-2}$ area. After harvesting, grains ear $^{-1}$ were recorded by counting grains in three ears randomly selected in each subplot and then averaged. After shelling the ears, thousand grains were selected randomly to record thousand grain-weights with the help of electronic balance form the produce of each subplot. Grain yield was recorded with the help of a spring balance after shelling all the ears harvested from the central four rows in each subplot. Grain yield thus obtained was then converted into $\mathrm{kg} \mathrm{ha}^{-1}$. Data on biological yield were also recorded from the whole biological matter harvested from the four central rows in each subplot at maturity. After harvest, the plants were sun dried and weighed using spring balance for calculating biological yield. Biological yield per sub plot was then converted into $\mathrm{kg} \mathrm{ha}{ }^{-1}$. Data were analyzed using a computer base statistical package "statistics (8.1)" [11] and the significant differences among the treatments were determined using least significant difference (LSD) test.

\section{Weather data for the maize growing period}

\section{weather data during the growth period}

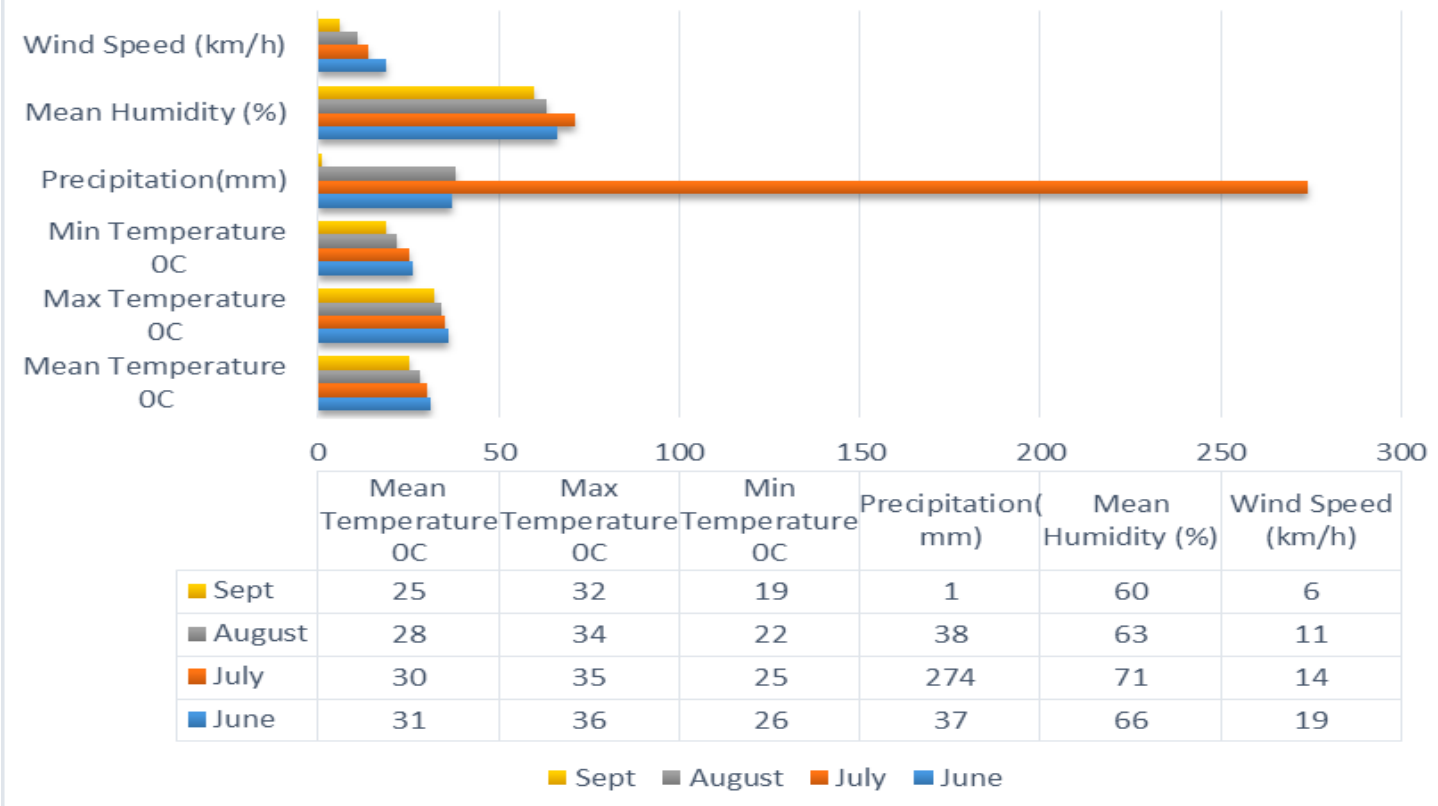

Results and discussion

\section{Plant height (cm)}

Significant differences were observed in average plant height of maize hybrids sown on various sowing dates; however, maize hybrids were not different from each in plant height. Data showed maximum plant height of maize sown on $15^{\text {th }}$ June $(232 \mathrm{~cm})$ while minimum plant height was noted in maize sown on $30^{\text {th }}$ June $(185 \mathrm{~cm})$. The possible reason could be that the early June sown crop had longer growth period to avail while end of June sown crop had shorter period for growth and therefore, taller and shorter plants were recorded in early and late sowing dates, respectively. Similar results were reported by [12-14] who stated that plant height was reduced by delayed sowing. [13, 15, 16] found that maize plant height was affected by the 
sowing date, but in their trials taller plants were obtained in the plots sown both on the earliest and late sowing dates.

Number of ears $\mathbf{~ m}^{-2}$

Data regarding ear $\mathrm{m}^{-2}$ are presented in Table 1. Statistical analysis of the data revealed that ears $\mathrm{m}^{-2}$ were significantly affected by maize hybrids, while sowing dates and the interaction of sowing dates and hybrids showed no effect on ears $\mathrm{m}^{-2}$. Mean values showed that higher number of 7 ears $\mathrm{m}^{-2}$ were produced by PIONEER30K08 followed by MALKA-TS-1105 with 5.9 ears while the minimum number of 4.8 ears $\mathrm{m}^{-2}$ was recorded in CS 200. [11, 12] reported significant differences among the maize hybrids for ears $\mathrm{m}^{-2}$. The possible reason is might be the genetic makeup of the maize hybrids that affected number of ears $\mathrm{m}^{-2}$.

\section{Number of grains ear ${ }^{-1}$}

Data regarding number of grains ear $^{-1}$ are presented in Table 1. Statistical analysis of the data revealed that number of grains ear ${ }^{-1}$ was significantly affected by the sowing dates and hybrids. The interaction of sowing dates and hybrids for grains ear ${ }^{-1}$ was nonsignificant. Data showed that higher number of grains ear-1 (563) was recorded when crop was sown on $15^{\text {th }}$ June followed by at par value of 560 grains ear ${ }^{-1}$ recorded in the June $15^{\text {th }}$ sown crop while minimum number of 460 grains ear $^{-1}$ was noticed in maize sown on $30^{\text {th }}$ June. [15, 17] found that delayed sowing of maize caused decrease in grain number and weight. The reason could be that the early sown crop got optimum growing period while the late crop got a shorter and cooler growing period which probably affected the process of fertilization and grain formation in the crop [13, 17]. Among the hybrids, MALKA-TS-1105 produced maximum number of 554 grains ear $^{-1}$ followed by PIONEER-30K08 with at par number of 534 grains ear ${ }^{-1}$, while significantly smaller number of 491 grains ear $^{-1}$ was recorded by CS 200. Differences in grains ear $^{-1}$ of the hybrids could be attributed to the genetic potential of the hybrids.

Table 1. Plant height, ears $\mathrm{m}^{-2}$ and grains ear-1 of maize hybrids as affected by various sowing Dates

\begin{tabular}{|c|c|c|c|}
\hline Treatment & Plant height (cm) & Ears m & Grains ear $^{-1}$ \\
\hline Sowing Date (SD) & \multicolumn{3}{|l|}{} \\
\hline $1^{\text {st }}$ June & $211 \mathrm{~b}$ & 5.7 & $560 \mathrm{a}$ \\
\hline $15^{\text {th }}$ June & $232 \mathrm{a}$ & 6.1 & $563 \mathrm{a}$ \\
\hline $30^{\text {th }}$ June & $185 \mathrm{c}$ & 5.8 & $460 \mathrm{~b}$ \\
\hline LSD $(0.05)$ & 12.0 & $\mathrm{~ns}$ & 62.6 \\
\hline Hybrid (H) & 213 & $4.8 \mathrm{c}$ & $491 \mathrm{~b}$ \\
\hline CS 200 & 203 & $7.0 \mathrm{a}$ & $534 \mathrm{a}$ \\
\hline PIONEER-30K08 & 212 & $5.9 \mathrm{~b}$ & $554 \mathrm{a}$ \\
\hline MALKA.TS.1105 & $\mathrm{ns}$ & 0.7 & 40.1 \\
\hline LSD $(0.05)$ & $\mathrm{ns}$ & $\mathrm{ns}$ & $\mathrm{Ns}$ \\
\hline Interaction $($ SD X H) & &
\end{tabular}

Means in the same category followed by different letters are significantly different at $\mathrm{P}$ $\leq 0.05$ level. $\mathrm{ns}=$ non-significant

\section{Thousand grain weight (g)}

Statistical analysis of the data showed that 1000-grains weight was significantly affected by maize hybrids while sowing Dates showed no effect on 1000-grains weight. The interaction of maize hybrids 
and sowing Dates was found significant for 1000-grains weight. Optimum 1000-grain weight of $460 \mathrm{~g}$ was produced the CS 200, while PIONEER-30K08 and MALKA-TS1105 produced $400 \mathrm{~g}$ and $370 \mathrm{~g}$ 1000-grain weights which both were at par with each other. [13, 14, 18] reported significant differences among maize hybrids for thousand grains weight. The interaction of sowing dates and maize hybrids for 1000grain weight was also found significant at $5 \%$ level of probability. It was noted that 1000-grain weight of MALKA-TS-1105 was the lowest $(340 \mathrm{~g}$ ) when sown on June $15^{\text {th }}$, which increased and boosted to $390 \mathrm{~g}$ when sown on June $15^{\text {th }}$ and June $30^{\text {th }}$. Thousand grain weight of PIONEER30K08 was stable i.e. 400, 390 and $400 \mathrm{~g}$ when sown on June $1 \mathrm{st}, 15^{\text {th }}$ and $30^{\text {th }}$ respectively. CS 200, on the other hand, produced $540 \mathrm{~g} 1000$ grains weight when sown on $1^{\text {st }}$ June which reduced to $440 \mathrm{~g}$ and again to $400 \mathrm{~g}$ when sown on June $15^{\text {th }}$ and $30^{\text {th }}$, respectively (Figure 1 ).

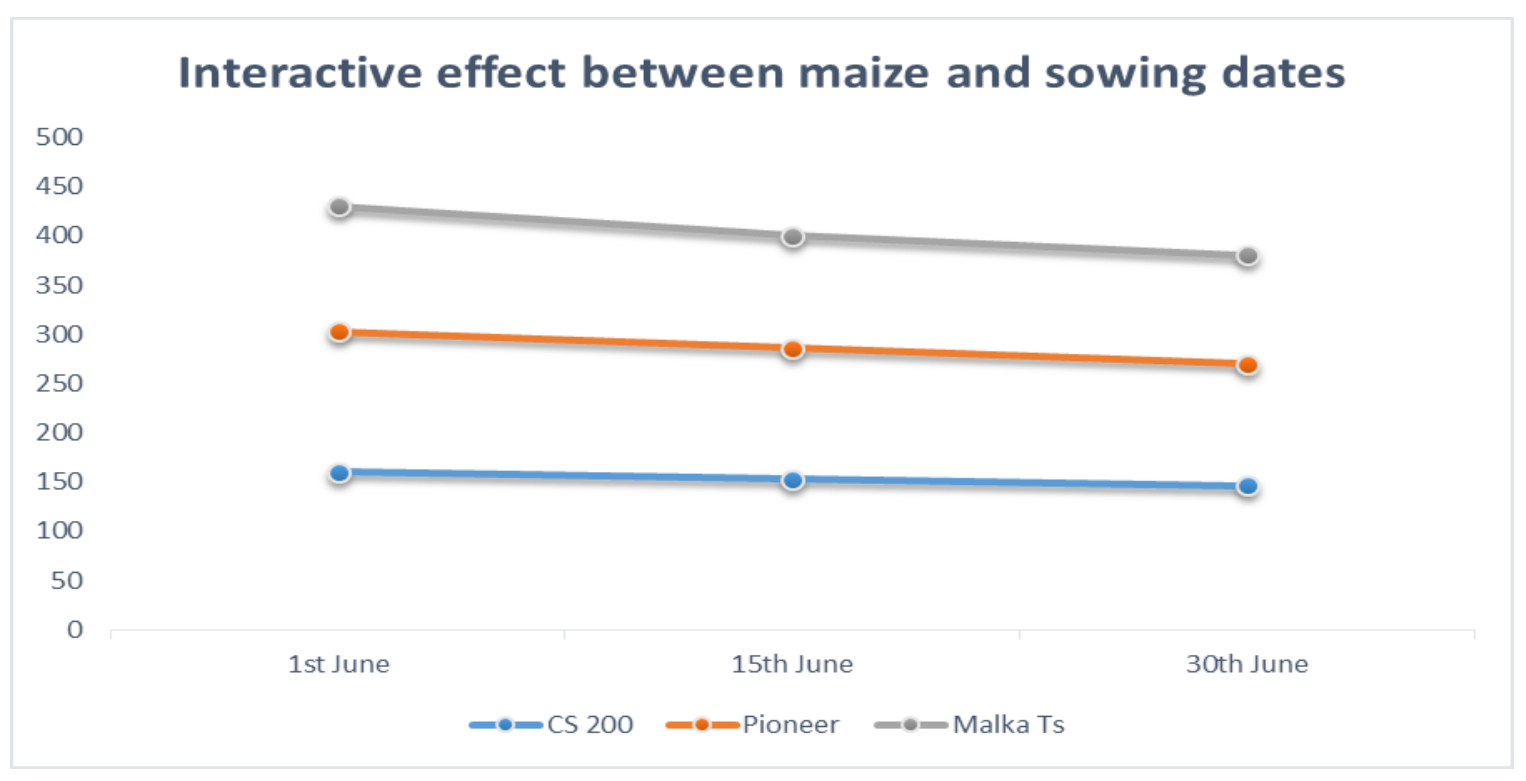

Figure 1. Interactive effect between Maize and sowing Dates

\section{Grain yield $\left(\mathrm{kg} \mathrm{ha}^{-1}\right)$}

Data regarding grain yield of maize hybrids as affected by sowing dates are presented in Table 2. Statistical analysis of the data revealed that grain yield was significantly affected by sowing dates. Maize hybrids also differed significantly from each other while the interaction effect of sowing dates and hybrids for grain yield was nonsignificant. Crop sown on $15^{\text {th }}$ June showed grain yield $\left(9010 \mathrm{~kg} \mathrm{ha}^{-1}\right)$ followed by at par grain yield of $7820 \mathrm{~kg} \mathrm{ha}^{-1}$ produced by the crop sown on June 15th. Minimum and significantly smaller grain yield $(6060 \mathrm{~kg}$ $\mathrm{ha}^{-1}$ ) was obtained by maize sown on $30^{\text {th }}$ June. Similar results were also obtained by
Gill and Mian [19] who reported that late sowing decreased grain yield. [20, 21] reported that higher grain yields were generally obtained when planting was completed by early May, while yield declined as planting was delayed. Reason for this variation in yield could be the longer growth period and comparatively mild temperature during the grain formation period. Among the maize hybrids, significantly larger grain yield $(8343 \mathrm{~kg}$ ha 1) was produced by PIONEER-30K08. CS 200 and MALKA-TS-1105 produced smaller and at par grain yields of 7415 and $7119 \mathrm{~kg} \mathrm{ha}^{-1}$, respectively. It showed the genetic superiority of the PIONEER-30K08 
over CS 200and MALKA-TS-1105 to produce higher grain yield. Among the yield components, ears $\mathrm{m}^{-2}$ and grains $\mathrm{ear}^{-1}$, probably contributed largely to the higher grain yield of the PIONEER-30K08.

\section{Biological yield ( $\left.\mathrm{kg} \mathrm{ha}^{-1}\right)$}

Data regarding biological yield of maize hybrids affected by sowing dates are presented in Table 2. Statistical analysis of the data revealed that biological yield was significantly affected by the sowing dates. Significant differences were noted among the maize hybrids in biological yield. The interaction effect of sowing dates and hybrids for the biological yield of hybrids was found non-significant. Data in Table 2 shows that at par biological yields of 25055 and $23240 \mathrm{~kg} \mathrm{ha}^{-1}$ were produced by the maize crop sown on $1^{\text {st }}$ and $15^{\text {th }}$ June while minimum biological yield (15972 $\mathrm{kg} \mathrm{ha}^{-1}$ ) was obtained by maize sown on $30^{\text {th }}$ June. $[16,22]$ observed decrease in above ground biomass when planting date was delayed from early March to mid-May in three different maturity groups of corn hybrids. Among the maize hybrids, at par biological yields of 22129 and $21907 \mathrm{~kg} \mathrm{ha}^{-1}$ were produced by PIONEER-30K08 and CS 200 while significantly lower biological yield of $20231 \mathrm{~kg} \mathrm{ha}^{-1}$ was obtained form MALKATS-1105. Higher biological yield of PIONEER-30K08 might be due to higher grain yield produced by the hybrid.

Table 2. Thousand grains weight (g), grain yield and biological yield of maize hybrids as affected by various sowing Dates

\begin{tabular}{|c|c|c|c|}
\hline Treatment & $\begin{array}{c}\mathbf{1 0 0 0} \text { grains weight } \\
(\mathbf{g})\end{array}$ & $\begin{array}{c}\text { Grain yield } \\
\left(\mathbf{k g ~ h a}^{-1}\right)\end{array}$ & $\begin{array}{c}\text { Biological yield } \\
\left(\mathbf{k g ~ h a}^{-1}\right)\end{array}$ \\
\hline Sowing date (SD) & \multicolumn{3}{|l|}{} \\
\hline $1^{\text {st }}$ June & 430 & $7820 \mathrm{a}$ & $25055 \mathrm{a}$ \\
\hline $15^{\text {th }}$ June & 410 & $9010 \mathrm{a}$ & $23240 \mathrm{a}$ \\
\hline $30^{\text {th June }}$ & 400 & $6060 \mathrm{~b}$ & $15972 \mathrm{~b}$ \\
\hline LSD $_{(0.05)}$ & $\mathrm{ns}$ & 1304 & 3290 \\
\hline Hybrid $(\mathrm{H})$ & \multicolumn{3}{|l}{} \\
\hline CS 200 & $460 \mathrm{a}$ & $7415 \mathrm{~b}$ & $21907 \mathrm{a}$ \\
\hline PIONEER-30K08 & $400 \mathrm{~b}$ & $8343 \mathrm{a}$ & $22129 \mathrm{a}$ \\
\hline MALKA-TS-1105 & $370 \mathrm{~b}$ & $7119 \mathrm{~b}$ & $20231 \mathrm{~b}$ \\
\hline LSD $(0.05)$ & 40.2 & 888.1 & 1338 \\
\hline Interaction (SD X H) & $*$ & $\mathrm{~ns}$ & $\mathrm{~ns}$ \\
\hline
\end{tabular}

Means in the same category followed by different letters are significantly different at $\mathrm{P} \leq 0.05$ level. ns $=$ non-significant

\section{Conclusion and recommendations}

It was concluded that among the hybrids PIONEER-30K08 produced significantly higher grain and biological yields followed by CS 200 and MALKA-TS-1105. Similarly, higher grain and biological yields were obtained when sowing was carried out on either $1^{\text {st }}$ or $15^{\text {th }}$ June as compared with $30^{\text {th }}$ June. Therefore, on the basis of higher grain yield, among the tested hybrids PIONEER-30K08 is recommended for sowing on either June 1 st or $15^{\text {th }}$ of maize under the agro-ecological zone of Swat valley.

\section{Authors' contributions}

Design the experiment, data collection and analysis: Imran, AA Khan \& S Shah, Technical help and revision of the manuscript: I Hussain, H Zada \& I Ullah, Downloaded the related review, data collection and interpretation of the data: $\mathrm{S}$ Naveed, S Din \& A Rahman, Wrote the paper: Imran. 


\section{Acknowledgement}

I am very much thankful to Mr. Fazal Karim, for the provision of demonstration plot (field) Muhammad Jibran Khan and Ikram Khan for the AESA (Agronomic Ecosystem Analysis), timely management of all agronomic practices and provision of inputs during the study period.

\section{References}

1. Martin HJ, Leonard WH \& Stamp DL (1975). Principles of Field Crop Production. $3^{\text {rd }}$ Ed. Mac. Publishing CO., Inc., New York.)

2. Shah SR (2007). Effect of seed priming on yield and yield components of maize. M.Sc. (Hons.) Thesis Deptt. of Agron. KP Agric. Univ., Peshawar, Pakistan. pp 1-73.

3. FAO (2007). Utilization of tropical foods: Food and Nutrition paper 4711, FAO, Rome.

4. MINFA (2011). Ministry of Food and Agriculture, Agriculture Statistics of Pakistan. Govt. of Pak, Economic Wing, Islamabad.

5. Inamullah, Shah NH, Rehman N, Siddiq M \& Khan Z (2011a). Phenology, yields and their correlations in popular local and exotic maize hybrids at various nitrogen levels. Sarhad J Agric 27(3): 363-369.

6. Inamullah, Rehman $\mathrm{N}$, Shah $\mathrm{NH}$, Arif $\mathrm{M}$, Siddiq M \& Mian I (2011b). Correlations among grain yield and yield attributes in maize hybrids in various nitrogen levels. Sarhad J Agric 27(4): 531-538.

7. Rafique M, Hussain A, Mahmood T, Alvi A W \& Alvi MB (2004). Heritability and interrelationships among grain yield and yield components in maize (Zea mays L.). Int'l J Agric \& Biol 6(6): 1113-1114.

8. Saleem AR, Saleem U \& Subhani GM (2007). Correlation and Path coefficient analysis in maize (Zea mays L.). J Agric Res 45(3):177183.

9. Sharlway $\mathrm{P}$, Zhelev R \& Etropolskv KM (1978). Bioproductivity, leaf area and root system of maize grown to different sowing dates. Exp Agri Res Bull 8(2): 7-12.

10. Abdel-Rahman AM, Magboul EL \& Nour AE (2001). Effects of sowing date and cultivar on yield and yield components of maize in Northern Sudan. $7^{\text {th }}$ Eastern and Southern Africa Regional Maize Conference, Nairobi, Kenya, 11-15 Feb, 2001. 295-298.
11. Russel F \& Eisensmith SP (1983). MSTATC. Crop \& Soil Sci. Deptt. Michigan State Univ. USA.)

12. Vasic N, Ivanovic M, Peternelli LA, Jockovic D, Stojakovic M \& Bocanski J (2001). Genetic relationship between grain yield and yield components in a synthetic maize population and their implications in selection. Acta Agronomica Hungarica 49(4): 337-342.

13. Imran \& Asad AK (2015). Grain Yield and Phenology of Maize Cultivars Influenced by Various Phosphorus Sources J Food Sci \& $Q$ Mang 37: 74-78.

14. Imran, Asad AK, Fayaz A \& Ullah I (2015). Influence of hydrated calcium Sulphate (caso4.2h2o) and nitrogen levels on water infiltration rate and maize varieties productivity in rainfed area of Swat, Pakistan. J. Chem \& M. Res. 7(3): 15-20.

15. Cirilo AG \& Andrade FH (1996). Sowing date and kernel weight in maize. Crop Sci 36: $325-331$.

16. Imran (2015). Effect of germination on proximate composition of two maize cultivars. J Bio agric \& $h$ Care 5(3)

17. Imran \& Asad AK (2015). Influence of Compost Application and Seed Rates on Production Potential of Late Sown Maize on High Elevation in Swat -Pakistan. J Environ \& E Sci 5 (5): 36- 40.

18. Yousaf M \& Saleem M (2001). Correlation analysis of $\mathrm{S} 1$ families of maize for grain yield and yield components. Int'l J Agric \& Biol. 3(4): 387-388.

19. Gill MS \& Mian A (1964). Effect of sowing dates and manures on the yield of maize of grain. Pak J Agri Res 1(2): 153-196.

20. Khan ZH, Shad KK, Nigar S, Khalil I, Haq I, Ahmad I, Ali A \& Khan MY (2009). Phenology and yield of sweet corn landraces influenced by planting dates. Sarhad J Agric 25(2): 153-157.

21. Widstrom NW, Youg JR, Martin WK \& Shaver EL (1984). Grain and forage yields of irrigated second crop corn seeded on five planting dates. Agron J 76(6): 883-886.

22. Garcia AG, Guerra LC \& Hoogenboom G (2009). Impact of planting date and hybrid on early growth of sweet corn. Agron J 101: 193-200. 